\title{
Nutrient Composition and Antioxidant Performances of Bread-Making Products Enriched with Stinging Nettle (Urtica dioica) Leaves
}

\author{
Annalisa Maietti, Paola Tedeschi, Martina Catani, Claudia Stevanin, Luisa Pasti, Alberto Cavazzini and \\ Nicola Marchetti * (D)
}

check for updates

Citation: Maietti, A.; Tedeschi, P.; Catani, M.; Stevanin, C.; Pasti, L.; Cavazzini, A.; Marchetti, N. Nutrient Composition and Antioxidant Performances of Bread-Making Products Enriched with Stinging Nettle (Urtica dioica) Leaves. Foods 2021, 10, 938. https://doi.org/ 10.3390 /foods 10050938

Academic Editors: Maria J Esteve and Jesus Blesa

Received: 2 March 2021

Accepted: 21 April 2021

Published: 25 April 2021

Publisher's Note: MDPI stays neutral with regard to jurisdictional claims in published maps and institutional affiliations.

Copyright: (c) 2021 by the authors. Licensee MDPI, Basel, Switzerland. This article is an open access article distributed under the terms and conditions of the Creative Commons Attribution (CC BY) license (https:// creativecommons.org/licenses/by/ $4.0 /)$.
Department of Chemistry, Pharmaceutical and Agricultural Sciences, University of Ferrara, via L. Borsari, 46-44121 Ferrara, Italy; mttnls@unife.it (A.M.); paola.tedeschi@unife.it (P.T.); martina.catani@unife.it (M.C.); claudia.stevanin@unife.it (C.S.); luisa.pasti@unife.it (L.P.); alberto.cavazzini@unife.it (A.C.)

* Correspondence: nicola.marchetti@unife.it; Tel.: +39-0532-455176

\begin{abstract}
Stinging nettle (Urtica dioica) is an edible plant, well-known for its nutritional and nutraceutical properties. Stinging nettle leaves are typically rich in fibers, minerals and vitamins, as well as antioxidant compounds, i.e., polyphenols and carotenoids. Due to these reasons, since ancient times stinging nettle has been widely used in Italy as an ingredient in foods and beverages as a therapeutic agent. This work provides an investigation focused on bread enrichment with nettle leaves and the improvement of bread proximate composition in minerals, fibers and antioxidant compounds during product preparation. The comparison between plain and nettle enriched white bread shows a significant increase in fibers and nutrients, i.e., calcium and copper levels. Nettle enrichment also provides an increase in lutein and $\beta$-carotene, as well as in total phenols and antioxidant activity. These last two nutritional elements are remarkably high in enriched bread and it has been found that phenolic concentration increases during breadmaking steps, from kneading to primary dough fermentation and from secondary fermentation of shaped loaves to baking.
\end{abstract}

Keywords: Urtica dioica; stinging nettle; enriched bread; minerals; dietary fibers; antioxidants

\section{Introduction}

Obesity and correlated diseases (i.e., cardiovascular diseases, diabetes and hypertension), have been grown in the last decades not only in industrialized countries but also in low and middle income countries. If the trend continues, by 2030 an estimated $38 \%$ of the world's adult population will be overweight, and another $20 \%$ will be obese [1]. Globalization has had profound effects on lifestyle that are linked with diet, activity and subsequent imbalance that have led to the current obesity epidemic. Westernization of the world's diet has involved reduction in fiber, whole grains, fruits and vegetables intake and an increase in refined carbohydrates and saturated fats [2]. Changes in eating patterns have resulted in an increase of energy dense meals and suboptimal nutrients intake, compared to the Recommended Daily Allowance (i.e., RDA). People who eat very few fruits and vegetables are likely to have an inadequate intake of many micronutrients, such as folic acid and vitamin C, and a consequent increment of the risks related to DNA damage, like cancer and other degenerative diseases. In addition, dietary deficiencies of micronutrients that are not derived primarily from fruits and vegetables, such as zinc, iron, and the vitamins E, niacin, B6 and B12, also seem to contribute to raise the risk of DNA damage [3].

Nowadays, food behavior begins to reverse the negative trends with major attention in health promotion. Consumers are increasingly concerned about their health and pay more attention to their lifestyle and the healthiness of their diet. The number of functional foods on the market is growing rapidly [4], and this trend looks set to continue in the future as well [5], with a growth rate of about $8-16 \%$ per year. Bread and bakery products are among 
the most consumed food in the world every day. They can be used as carriers to increase healthy compounds intake such as minerals, vitamins and antioxidants. Spices [6,7], marine foods [8], processing by-products of plant foods [9,10], cereals by products [11] and omega3 fatty acids [12] are some of the ingredients that could be included in bread formulation. Urtica dioica is a wild comestible plant and it has been served as food since ancient times, in particular for salad, seasoning, soups and herbal infusions $[13,14]$. Stinging nettle is an important source of minerals and vitamins, including calcium, iron, magnesium, phosphorus, potassium, sodium, ascorbic acid and B-complex. It also contains a relevant amount of proteins, chlorophylls and carotenoids, such as $\beta$-carotene and lutein. Stinging nettle leaves are also rich in polyphenols, mainly flavonoids (i.e., kaempferol, isorhamnetin, quercetin, and their rutinoside or glycoside derivatives) and phenolic acids (i.e., caffeic acid and its ester derivatives, like chlorogenic acid and caffeoylmalic acid) [15].

In some recent works $[16,17]$, polyphenols and carotenoids in stinging nettle leaves were determined in a quantitative way, and both the bioaccessibility and bioavailability of micronutrients and plant metabolites from enriched foods were investigated by means of in-vitro gastro-intestinal simulated digestion. The addition of dried, powdered nettle leaves to fresh egg pasta dough can increase both polyphenols and carotenoids intake, and the functional properties of this enriched food can be effectively improved with favorable fallouts to prevent the adverse effects of oxidative stress on biological structures and tissues. In this study, frozen chopped nettle leaves are added to bread dough with the aim to investigate the proximate composition of enriched bread vs. plain white bread during the bread-making and to improving the nutritional intake of minerals, fiber and antioxidant compounds.

\section{Materials and Methods}

\subsection{Bread Making}

The bread samples studied in this work were produced by a local firm (Vassalli bakering S.r.l, Ferrara, Italy) leader in frozen precooked bread production for large-scale retail trade and collective catering. Ingredients for the white bread were: $1 \mathrm{~kg}$ of flour type " 00 " (ash $=0.46 \%$, moisture $=12.5 \%$ ); $500 \mathrm{~mL}$ of water; $40 \mathrm{~g}$ of extra-virgin olive oil; $30 \mathrm{~g}$ of yeast; $20 \mathrm{~g}$ of NaCl; $10 \mathrm{~g}$ of enzyme ( $\alpha$ and $\beta$ amylase). Nettle-enriched bread was obtained by adding $100 \mathrm{~g}$ of frozen chopped nettle leaves (particle size $1-3 \mathrm{~mm}$ ) to white bread ingredients during the kneading step. Frozen chopped nettle leaves were commercialized by the following industrial supplier: Tecniche Moderne Surgelati S.r.l. (Ravarino, Modena, Italy). The amount of nettle used for enriched bread was determined as the maximum quantity that does not affect at the same time the proper, efficient kneading of all ingredients and the acceptable organoleptic properties of baked enriched bread. This enabled keeping ingredients unaltered with no need to modify their weight ratio in enriched bread with respect to plain white. No major differences in stickiness and texture were evidenced between the two doughs. These unaltered mechanic properties of enriched dough, together with unchanged activities of yeast and enzymes, allow having uniform, consistent leavening for the two products. Among the organoleptic properties of baked enriched bread, particular attention has been paid to taste, since this can be negatively affected by some phytoconstituents (i.e., chlorophylls) in terms of bitterness and astringency.

Both plain and nettle enriched doughs (kneaded and fermented) were partially baked at $190{ }^{\circ} \mathrm{C}$ for $12 \mathrm{~min}$ and, then, frozen at $-18{ }^{\circ} \mathrm{C}$ in a pilot plant. Final baked products consisted of bread rolls (white and nettle enriched) that were fully oven-cooked at $200{ }^{\circ} \mathrm{C}$ for $5 \mathrm{~min}$. The bread making process of both bread type (i.e., white and nettle enriched) was repeated in triplicate, and five samples were collected and stored at $-20{ }^{\circ} \mathrm{C}$ from the following phases: kneading, leavening, prebaking (i.e., partially baked bread) and baking (i.e., fully baked bread). For each phase and for each bread type the samples were homogenized and analyzed in triplicate. 


\subsection{Proximate Composition}

Methods of analysis by Association of Official Analytical Chemists (AOAC, 1984 [18]) were adopted to determine sample proximate composition. Moisture content was determined by drying the samples at $105^{\circ} \mathrm{C}$ to a constant weight. Moisture was expressed as $\mathrm{g}$ of water per $100 \mathrm{~g}$ of fresh weight $\left(\mathrm{g} / 100 \mathrm{~g}_{\mathrm{fw}}\right)$. Total nitrogen compounds were determined on $1 \mathrm{~g}$ of dry matter by technically revised Kjeldahl method by International Organization for Standardization (ISO 8968-3:2004) [19] that replaces previous IDF 20-3:1993 method by International Dairy Federation. The protein content was determined by means of a conversion factor equal to 6.25 (Kjeldahl digestion unit and Kjeldahl distillation unit made from VELP Scientifica, Usmate, MB, Italy). Ashes were determined by the incineration of $1 \mathrm{~g}$ of dry matter placed in a muffle furnace (VELP Scientifica, Usmate, MB, Italy) at $570{ }^{\circ} \mathrm{C}$ for $5 \mathrm{~h}$. Total lipids were determined by gas-chromatography after soxhlet extraction (VELP Scientifica, Usmate, MB, Italy). Gas-chromatographic runs were done after fatty acid transesterification with $1.5 \mathrm{~mL}$ of $5 \% \mathrm{NaOH}$ solution in methanol. Sample volume of $1 \mu \mathrm{L}$ was injected into the gas chromatography-mass spectrometry (GC-MS) apparatus. MS detector was a Varian Saturn 2100 MS/MS ion trap mass spectrometer. MS data acquisitions were performed in full-scan mode. Separations were obtained by using a Zebron ZB-WAX (Phenomenex) capillary column $(60 \mathrm{~cm}$ length, $0.25 \mathrm{~mm}$ i.d.) and helium as carrier gas at $1 \mathrm{~mL} / \mathrm{min}$ constant flow. The injector temperature was set up at $250{ }^{\circ} \mathrm{C}$ and the oven temperature program was isothermal at $100^{\circ} \mathrm{C}$ for $2 \mathrm{~min}$, then temperature was increased up to $200{ }^{\circ} \mathrm{C}$ at $10{ }^{\circ} \mathrm{C} / \mathrm{min}$, then isothermal at $200{ }^{\circ} \mathrm{C}$ for $108 \mathrm{~min}$. This was employed for fatty acids profiling in both frozen chopped nettle and enriched bread. Insoluble dietary fiber (IDF) and soluble dietary fiber (SDF) were determined as reported by the instruction protocol developed for the Megazyme Total Dietary Fiber Assay Kit (Megazyme International, Co. Wicklow, Ireland), based on the combined enzymatic and gravimetric method by Prosky et al. [20] and by Lee et al. [21]. All other carbohydrates were estimated by difference. Results were expressed as $\mathrm{g} / 100 \mathrm{~g}_{\mathrm{fw}}$.

\subsection{Inorganic Composition}

A Perkin-Elmer (Perkin-Elmer, Inc.,Waltham, MA, USA) Atomic Absorption Spectrometer (AAS) was used for mineral element analysis, after nitric acid digestion by an acid-assisted microwave irradiation. All samples were digested in triplicate by using a published method [22]. $1 \mathrm{~g}$ of dry matter $(\mathrm{dm})$ was placed in the microwave vessel and $5 \mathrm{~mL}$ of concentrated $\mathrm{HNO}_{3}$ were added and submitted to a digestion cycle (ramp: $200{ }^{\circ} \mathrm{C}$ in $20 \mathrm{~min}$, hold for $10 \mathrm{~min}$ ). After cooling, $1 \mathrm{~mL}$ of $\mathrm{H}_{2} \mathrm{O}_{2}$ was added and the mixture was submitted to another digestion cycle until the oxidation of the organic matter was completed. Each digested solution was diluted with ultrapure water unto a final volume of $20 \mathrm{~mL}$ after cooling.

\subsection{Extraction of Phenolic Compounds}

A portion of chopped nettle and each bread sample were dried at $60{ }^{\circ} \mathrm{C}$ and then ground with a knife mill Retsch GM200 (Retsch Verder Scientific S.r.l., Torre Boldone, Bergamo, Italy) at $2500 \mathrm{rpm}$ for $30 \mathrm{~s}$ to obtain a dry powder. The extraction of phenolic compounds from samples was carried out using a method proposed by Pérez-Jiménez and Saura-Calixto [23], with some modifications [16]. Briefly, $2 \mathrm{~g}$ of nettle powder or $5 \mathrm{~g}$ of bread powders were placed in a test tube with $15 \mathrm{~mL}$ of a mixture of methanol/water (80:20) acidified with $0.1 \%$ of formic acid and homogenized by an T18 basic Ultraturrax $\left(\mathrm{IKA}^{\circledR}\right.$-Werke GmbH \& Co. KG, Staufen, Germany) for $2 \mathrm{~min}$. The sample was extracted three times and after each step, samples were centrifuged (Centrifuge Thermo PK121R, Thermo Fisher Scientific, Waltham, MA, USA) at $2500 \mathrm{~g}$ for $5 \mathrm{~min}$ at $4{ }^{\circ} \mathrm{C}$, and supernatants were recovered and combined. 


\subsection{Total Phenols Content (TPC) and Antioxidant Activity (TEAC)}

The amount of total phenols (TPC) in extracted samples was measured using the Folin Ciocalteu assay as described by Singleton et al. [24]. The results are expressed as $\mu \mathrm{g}$ of gallic acid equivalents per $\mathrm{g}$ of fresh weight $(\mathrm{fw}), \mu \mathrm{g}_{\mathrm{GAE}} / \mathrm{g}_{\mathrm{fw}}$ Antioxidant activity of the extracts was measured by using the Trolox equivalent antioxidant capacity (TEAC) assay based on scavenging of 2,2'-azinobis-(3-ethylbenzothiazoline-6-sulfonic acid) radical $\left(\mathrm{ABTS}^{\bullet+}\right.$ ) as reported by Re et al. [25]. Results were expressed as mg of trolox equivalents per $g$ of fresh weight, $\mathrm{mg}_{\mathrm{TE}} / \mathrm{g}_{\mathrm{fw}}$.

\subsection{Extraction and Analysis of Carotenoids}

Carotenoids were extracted from dried powder samples using the method developed by Panfili et al. [26], slightly modified in our laboratory [17]. About $0.15 \mathrm{~g}$ of nettle powder or $1.5 \mathrm{~g}$ of bread powders were placed in a test tube with $5 \mathrm{~mL}$ of Pyrogallol $60 \mathrm{~g} / \mathrm{L}$ solution in Ethanol, $2 \mathrm{~mL}$ of Ethanol, $2 \mathrm{~mL}$ of $\mathrm{NaCl} 10 \mathrm{~g} / \mathrm{L}$ aqueous solution and $2 \mathrm{~mL}$ of $\mathrm{KOH}$ $600 \mathrm{~g} / \mathrm{L}$ aqueous solution. After homogenization with Ultraturrax $\left(\mathrm{IKA}^{\circledR}\right.$-Werke $\mathrm{GmbH}$ \& Co. KG) for $1 \mathrm{~min}$, the samples were shaken for $45 \mathrm{~min}$ at $70{ }^{\circ} \mathrm{C}$, cooled in an ice bath for $5 \mathrm{~min}$ and $15 \mathrm{~mL}$ of $\mathrm{NaCl}(10 \mathrm{~g} / \mathrm{L})$ were added at last. Samples were extracted twice with $15 \mathrm{~mL}$ hexane: ethyl acetate 9:1 added by BHT $0.1 \% w / v$. The organic phase was evaporated using a rotary evaporator and the dried extract was resuspended with $2 \mathrm{~mL}$ of mobile phase for HPLC analysis. The analysis of carotenoids was carried out using a previously developed method [27] based on an HPLC Agilent 1100 (Agilent Inc., Santa Clara, CA, USA) equipped with DAD detector and C30 Develosil RP-Aqueous $150 \times 3.0 \mathrm{~mm}$ column (Phenomenex, Torrance, CA, USA). Mobile phases employed were binary mixtures of water and acetonitrile 70:30 $v / v$ (solvent A) and methanol and methyl tert-butyl ether 50:50 v/v (solvent B). Eluent composition was programmed as in the following by changing the amount of solvent B: from $20 \%$ to $47 \%$ in $10 \mathrm{~min}$, from $47 \%$ to $57 \%$ in $10 \mathrm{~min}$, and then from $57 \%$ to $100 \%$ in $20 \mathrm{~min}$. The flow rate was $0.4 \mathrm{~mL} / \mathrm{min}$ and the injection volume was $5 \mu \mathrm{L}$. The spectrophotometric detection was done at $450 \mathrm{~nm}$.

\subsection{Statistical Analysis}

Data are presented as means \pm SD of three parallel measurements. Differences between bread samples were analyzed by ANOVA using SPSS v. 22.0 software (SPSS Inc., Chicago, IL, USA). $p$ values $<0.05$ was regarded as significant.

\section{Results and Discussion}

\subsection{Chemical Composition of Frozen Chopped Nettle}

In a recent literature work [28] dried nettle was compared to barley and wheat flours in terms of their main nutritional components, and results evidenced that dried nettle has a higher content of protein, fibers, fat, ash, calcium, iron, and antioxidant compounds such as tannins, total polyphenols and carotenoids than cereal flours. With regard to the uptake of metals by plants, it is already known that this is strongly influenced by different factors, including type of plant, nature of soil, climate, and agriculture practices. Also, nettle plants can selectively absorb some elements from soil, as it has been proven by a literature work where among 30 medicinal herbal samples analyzed by ICP-MS [29] the highest levels of iron, copper and zinc were found in stinging nettle. Additionally, another study has been shown a high correlation between $\mathrm{Fe}, \mathrm{Mn}, \mathrm{Cu}$, and $\mathrm{K}$ concentrations in soil and their levels in the aerial part of nettle leaves [30]. The chemical composition nettle used in this study has been determined and listed in Table 1. Values are reported as grams per $100 \mathrm{~g}$ of fresh weight $\left(\mathrm{g} / 100 \mathrm{~g}_{\mathrm{fw}}\right)$. Nettle displayed a higher content of ashes and total dietary fiber than " 00 " flour normally used for bread making. The high level of mineral fraction is mainly due to $\mathrm{Ca}\left(6764 \mu \mathrm{g} / \mathrm{g}_{\mathrm{fw}}\right)$ and $\mathrm{K}\left(6456 \mu \mathrm{g} / \mathrm{g}_{\mathrm{fw}}\right)$, while Fe and $\mathrm{Cu}$ content were $67.63 \mu \mathrm{g} / \mathrm{g}_{\mathrm{fw}}$ and $190.6 \mu \mathrm{g} / \mathrm{g}_{\mathrm{fw}}$, respectively (see Table 2). Some therapeutic benefits of nettle are attributed to its secondary metabolites (phenolic compounds, carotenes, essential oil) and to its antioxidant activity [31]. TPC, antioxidant activity and concentration of lutein 
and $\beta$-carotene were determined; these values are reported in Table 3. The nettle sample displays the following characteristics: TPC equals $824 \mu \mathrm{g}_{\mathrm{CE}} / \mathrm{g}_{\mathrm{fw}}, 67.85 \mu \mathrm{g} / \mathrm{g}_{\mathrm{fw}}$ of lutein and $5.70 \mu \mathrm{g} / \mathrm{g}_{\mathrm{fw}}$ of $\beta$-carotene. The antioxidant activity determined by TEAC assay was $0.89 \mathrm{mg} / \mathrm{g}_{\mathrm{fw}}$.

Table 1. Proximate composition of frozen chopped nettle.

\begin{tabular}{|c|c|c|}
\hline \multicolumn{2}{|c|}{ Component } & \multirow{2}{*}{$\begin{array}{l}\mathbf{g} / \mathbf{1 0 0}_{\mathbf{f w}_{\mathbf{w}}} \mathbf{1} \\
79.8 \pm 0.6\end{array}$} \\
\hline Moisture & - & \\
\hline Proteins & - & $3.50 \pm 0.02$ \\
\hline Fats & - & $0.17 \pm 0.04$ \\
\hline Ashes & - & $3.38 \pm 0.17$ \\
\hline Carbohydrates & - & $5.03 \pm 0.28$ \\
\hline Total fiber & - & $8.15 \pm 0.27$ \\
\hline- & Soluble & $1.55 \pm 0.24$ \\
\hline - & Insoluble & $6.60 \pm 0.51$ \\
\hline
\end{tabular}

${ }^{1}$ values are expressed as mean $\pm \mathrm{SD}, n=3$.

Table 2. Ashes composition of frozen chopped nettle.

\begin{tabular}{cc}
\hline Component & $\left(\boldsymbol{\mu g} / \mathbf{g}_{\mathbf{f w}}\right)^{\mathbf{1}}$ \\
\hline Calcium & $6764 \pm 220$ \\
Potassium & $6456 \pm 163$ \\
Magnesium & $845.4 \pm 7.1$ \\
Copper & $190.6 \pm 8.1$ \\
Iron & $67.63 \pm 0.57$ \\
Sodium & $32.25 \pm 5.16$ \\
Zinc & $6.920 \pm 1.150$ \\
\hline
\end{tabular}

${ }^{1}$ values are expressed as mean $\pm \mathrm{SD}, n=3$.

Table 3. Antioxidant compounds in frozen chopped nettle.

\begin{tabular}{cc}
\hline Component & Nettle $^{\mathbf{1}}$ \\
\hline TPC $\left(\mu g_{\mathrm{GAE}} / \mathrm{g}_{\mathrm{fw}}\right)^{2}$ & $755 \pm 21$ \\
$\mathrm{TEAC}\left(\mathrm{mg}_{\mathrm{TE}} / \mathrm{g}_{\mathrm{fw}}\right)^{3}$ & $0.89 \pm 0.07$ \\
Lutein $\left(\mu \mathrm{g} / \mathrm{g}_{\mathrm{fw}}\right)$ & $67.8 \pm 4.1$ \\
$\beta$-carotene $\left(\mu \mathrm{g} / \mathrm{g}_{\mathrm{fw}}\right)$ & $5.70 \pm 0.59$ \\
\hline
\end{tabular}

TPC, total phenols content. TEAC, antioxidant activity. ${ }^{1}$ values are expressed as mean $\pm \mathrm{SD}, n=3 .{ }^{2} \mu \mathrm{g}$ of gallic acid equivalents (GAE) per $\mathrm{g}$ of fresh weight $(\mathrm{fw}){ }^{3} \mathrm{mg}$ of trolox equivalents (TE) per $\mathrm{g}$ of fresh weight (fw).

\subsection{White vs. Enriched Nettle Bread Proximate Composition}

The chemical composition of white bread and nettle enriched bread are expressed per $100 \mathrm{~g}$ of fresh product and are reported in Table 4 . Amount of moisture, proteins and carbohydrates in white bread were similar to those in nettle bread. The addition of nettle to the dough significantly increased ashes content from 1.28 to $1.75 \mathrm{~g} / 100 \mathrm{~g}_{\mathrm{fw}}$ and dietary fibers content from 0.57 to $1.22 \mathrm{~g} / 100 \mathrm{~g}_{\mathrm{fw}}$. Conversely, amount of fats decreased $(p<0.05)$ from 2.51 to $2.13 \mathrm{~g} / 100 \mathrm{~g}_{\mathrm{fw}}$ between white and enriched bread. Results are in agreement with other literature findings [32], where nettle powder was used to enrich other foods but with reduced sensory acceptability, i.e., noodles that are higher in proteins, ashes and fibers. In our study, the enrichment with nettle produces only slight modifications on organoleptic characteristics of white bread (i.e., color and flavor), but it does not increase the content of proteins. 
Table 4. Proximate composition of white bread and nettle enriched bread.

\begin{tabular}{|c|c|c|}
\hline Component & White Bread ${ }^{1}$ & Nettle Enriched Bread ${ }^{1}$ \\
\hline Moisture & $26.85 \pm 2.67$ & $28.46 \pm 2.46$ \\
\hline Proteins & $9.50 \pm 0.61$ & $8.97 \pm 0.01$ \\
\hline Fats * & $2.51 \pm 0.06$ & $2.13 \pm 0.03$ \\
\hline Ashes * & $1.28 \pm 0.01$ & $1.75 \pm 0.04$ \\
\hline Carbohydrates & $60.34 \pm 1.35$ & $58.47 \pm 2.37$ \\
\hline Total fiber * & $0.53 \pm 0.03$ & $1.22 \pm 0.09$ \\
\hline
\end{tabular}

${ }_{1}^{1}$ values are expressed as $\mathrm{g} / 100 \mathrm{~g}_{\mathrm{fw}}$ and reported as mean $\pm \mathrm{SD}, n=3 .{ }^{*}$ significantly different at $p<0.05$.

The mineral composition of ashes was investigated by atomic spectroscopy and the results obtained are reported in Table 5. Ingredients used for white and enriched bread were the same and the observed increment was only due to nettle added. Sodium display the higher amount because $20 \mathrm{~g}$ of salt have been added to both bread types. Also, potassium was determined at high concentrations (1457 and $1877 \mu \mathrm{g} / \mathrm{g}_{\mathrm{fw}}$ in white and nettle enriched bread, respectively). A significant increment of calcium, copper and a moderate increment $(p<0.05)$ of iron were observed in nettle enriched bread. After nettle addition, calcium concentration increases about four times (from $126 \mu \mathrm{g} / \mathrm{g}_{\mathrm{fw}}$ to $559 \mu \mathrm{g} / \mathrm{g}_{\mathrm{fw}}$ ) while copper concentration rises roughly eight times (from $2.35 \mu \mathrm{g} / \mathrm{g}_{\mathrm{fw}}$ to $16.51 \mu \mathrm{g} / \mathrm{g}_{\mathrm{fw}}$ ). RDA for calcium is set at $800-1200 \mathrm{mg} /$ day for adults in Italy, and it has been reported [33] that Ca intake with an Italian diet only allows for meeting $76 \%$ of the RDA value. This confirms the trend evidenced by other studies performed in different European countries. Assuming a bread intake of $100 \mathrm{~g} /$ day, the nettle enrichment bread supplies the 5-7\% of Ca RDA toward 1.05-1.58 of the white bread. Copper and iron are trace elements involved in cell oxidation and signaling systems. They act as cofactors in several enzymatic reactions that play a critical role in several metabolic pathways. The Italian RDAs are $900 \mu \mathrm{g} / \mathrm{day}$ for $\mathrm{Cu}$ and $10-15 \mathrm{mg} /$ day for iron in adults. The intake of copper determined in the Italian diet is estimated to be high enough [33]; however, the human gastrointestinal system can absorb only $30-40 \%$ of ingested copper from the diet [34]. In the Italian diet the daily iron intake is $12.7 \mathrm{mg}$, of which about $89 \%$ is non-haem iron [33]. Absorption of non-haem iron is usually lower than $10 \%$ [35]. The consumption of $100 \mathrm{~g} /$ day of enrichment bread supplies the $10-15 \%$ of RDA for Fe and $74 \%$ for $\mathrm{Cu}$.

Table 5. Ashes composition of white bread and nettle enriched bread.

\begin{tabular}{|c|c|c|}
\hline Component & White Bread $^{1}$ & Nettle Enriched Bread ${ }^{1}$ \\
\hline Calcium * & $126 \pm 8$ & $559 \pm 27$ \\
\hline Magnesium & $181 \pm 10$ & $245 \pm 19$ \\
\hline Potassium & $1457 \pm 58$ & $1877 \pm 192$ \\
\hline Sodium & $7384 \pm 597$ & $6928 \pm 371$ \\
\hline Copper* & $2.35 \pm 0.12$ & $16.51 \pm 0.61$ \\
\hline Iron * & $11.77 \pm 0.26$ & $15.26 \pm 1.00$ \\
\hline Zinc & $7.26 \pm 0.42$ & $7.00 \pm 0.28$ \\
\hline Manganese & $4.35 \pm 0.25$ & $5.32 \pm 0.21$ \\
\hline
\end{tabular}

${ }^{1}$ values are expressed as $\mu \mathrm{g} / \mathrm{g}_{\mathrm{fw}}$ and reported as mean $\pm \mathrm{SD}, n=3$. ${ }^{*}$ significantly different at $p<0.05$.

For the sake of completeness, fatty acids profile for both frozen chopped nettle and enriched bread revealed that nettle mainly contains (relative amount on a fresh matter basis) $26.1 \% \pm 0.4 \%$ Palmitic (C16:0), 28.2\% $\pm 1.9 \%$ Linoleic (C18:2), $22.1 \% \pm 1.9 \%$ Linolenic (C18:3) and 13.0\% $\pm 1.1 \%$ Oleic (C18:1), $6.1 \% \pm 0.5 \%$ Stearic (C18:0) and $2.4 \% \pm 1.0 \%$ Arachidic (C20:0). Enriched bread, instead, displays the same lipidic profile of extravirgin olive oil added to the dough: $71.8 \% \pm 0.1 \%$ Oleic (C18:1), $12.2 \% \pm 0.2 \%$ Palmitic (C16:0), 9.7\% $\pm 0.1 \%$ Linoleic (C18:2) and $4.6 \% \pm 0.1 \%$ Stearic (C18:0). No differences were evidenced between white bread and nettle enriched bread regarding fatty acid profile. 


\subsection{Influence of Nettle Addition on Antioxidant Compounds of Bread}

Antioxidant activity of plants have been associated with their ability to prevent disorders like cancer, diabetes, cardiovascular diseases, autoimmune diseases, neurodegenerative disorders and aging. Most of the antioxidant activity of plants is due to the presences of secondary metabolites like polyphenols and carotenoids. On one hand, bread wheat (Triticum aestivum subsp. aestivum) contains very limited quantities of carotenoids and phenolics. In the whole grain, these compounds exist mainly in the bran and germ portions, where they are covalently cross-linked with cell wall carbohydrate polymers. Starchy endosperm is separated from bran and germ portions by milling process and only the first fraction produces four, whereas the last two are commonly discarded and used for animal feeding $[36,37]$. On the other hand, nettle leaves (Urtica dioica variety) are rich in phytoconstituents, mainly polyphenols, flavonoids (kaempferol, isorhamnetin, quercetin, isoquercitrin and rutin) and phenolic acids (caffeic acid and chlorogenic acid), and carotenoids ( $\beta$-carotene, hydroxyl- $\beta$-carotene, luteoxanthin, lutein epoxide, and violaxanthin), but also essential oils, fatty acids and other constituents (minerals and vitamins) [31].

Many studies have been conducted on the topic of bread enrichment with pseudocereals [38] or with spices, herbs and the green edible part of plants [39,40]. In this context, it is interesting to study the antioxidant properties of nettle enriched bread. Thus, antioxidant activity, polyphenols, $\beta$-carotene and lutein contents of white and nettle enriched breads are assayed in this work and they are reported in Table 6. TPC value increases from $372 \mu \mathrm{g}_{\mathrm{GAE}} / \mathrm{g}_{\mathrm{fw}}$ in white bread to $597 \mu \mathrm{g}_{\mathrm{GAE}} / \mathrm{g}_{\mathrm{fw}}$ in nettle enriched one. Nettle leaves contain plenty of antioxidant compounds and those used in this study have been characterized (see Table 3). As expected, the antioxidant activity is higher in enriched bread than in plain white (i.e., 0.83 vs. $0.53 \mathrm{mg}_{\mathrm{TE}} / \mathrm{g}_{\mathrm{fw}}$, respectively). Therefore, nettle addition provides a significant increase of total phenols and an increment $(p<0.05)$ of antioxidant activity.

Table 6. Antioxidant compounds of white bread and nettle enriched bread.

\begin{tabular}{ccc}
\hline Component & White Bread $^{\mathbf{1}}$ & Nettle Enriched Bread $^{\mathbf{1}}$ \\
\hline $\mathrm{TPC}^{*}\left(\mu \mathrm{g}_{\mathrm{GAE}} / \mathrm{g}_{\mathrm{fw}}\right)^{2}$ & $372 \pm 14$ & $597 \pm 17$ \\
$\left.\mathrm{TEAC}^{2} \mathrm{mg}_{\mathrm{TE}} / \mathrm{g}_{\mathrm{fw}}\right)^{3}$ & $0.53 \pm 0.07$ & $0.83 \pm 0.08$ \\
Lutein $^{*}\left(\mu \mathrm{g} / \mathrm{g}_{\mathrm{fw}}\right)$ & $1.46 \pm 0.11$ & $3.97 \pm 0.54$ \\
$\beta$-carotene ${ }^{*}\left(\mu \mathrm{g} / \mathrm{g}_{\mathrm{fw}}\right)$ & $0.41 \pm 0.07$ & $0.72 \pm 0.10$ \\
\hline
\end{tabular}

${ }^{1}$ values are expressed as mean $\pm \mathrm{SD}, n=3 .{ }^{2} \mu \mathrm{g}$ of gallic acid equivalents (GAE) per g of fresh weight (fw). ${ }^{3} \mathrm{mg}$ of trolox equivalents (TE) per $\mathrm{g}$ of fresh weight (fw). * significantly different at $p<0.05$.

$\beta$-carotene and lutein are quantitatively determined by using external calibration method. Area vs. concentration data have been fitted to a linear regression model and correlation coefficients were 0.9969 for $\beta$-carotene and 0.9987 for lutein. Nettle addition to bread significantly improves $(p<0.05) \beta$-carotene and lutein contents from $0.412 \mu \mathrm{g} / \mathrm{g}_{\mathrm{fw}}$ to $0.723 \mu \mathrm{g} / \mathrm{g}_{\mathrm{fw}}$ and from $1.46 \mu \mathrm{g} / \mathrm{g}_{\mathrm{fw}}$ to $3.97 \mu \mathrm{g} / \mathrm{g}_{\mathrm{fw}}$, respectively. Raw chopped nettle is used to enrich white bread displayed lutein and $\beta$-carotene contents of $67.8 \mu \mathrm{g} / \mathrm{g}_{\mathrm{fw}}$ and $5.70 \mu \mathrm{g} / \mathrm{g}_{\mathrm{fw}}$, respectively (see Table 3). If we consider that this ingredient is added in terms of $10 \% \mathrm{w} / \mathrm{w}$ to bread dough, we would have expected higher values for both carotenoids then what we have found (i.e., $8.245 \mathrm{vs} .3 .97 \mu \mathrm{g} / \mathrm{g}_{\mathrm{fw}}$ for lutein and $0.982 \mathrm{vs.} 0.31 \mu \mathrm{g} / \mathrm{g}_{\mathrm{fw}}$ for $\beta$-carotene). Carotenoids are lipophilic molecules that are sensitive to thermal and enzymatic degradation, which may explain the lower content of $\beta$-carotene and lutein observed after bread additivation. Wheat contains enzymes such as lipoxygenase and peroxidase which become active when water is added to flour and can lead to oxidation of carotenoid pigments [41]. Moreover, carotenoids degradation may be mostly related to their susceptibility to heat during baking [42].

All chemical parameters determined and discussed in terms of proximate composition (i.e., inorganic elements, ashes, proteins) have been estimated for both white and nettle bread and for intermediate products during the baking process (kneading fermentation, prebaking, baking). However, these latter findings are not reported because no significant 
differences were found. The increase of these values with bread baking is low and most likely due to the loss of water during the cooking procedure. The breadmaking process consists of three basic operations: mixing, fermentation and baking. Some studies show how the antioxidant potential in bakery products is connected to manufacturing formulation and conditions. In particular, the antioxidant activity and residual content of free phenolic acids of flour were reduced by mixing, but increased by fermentation and baking [43]. A microbial hydrolysis reaction takes place during fermentation and this is probably responsible for the greater content of phenolic compounds and flavonoids. It is widely reported in literature that fermentation induces the breakdown of bran cell wall structure, and this leads to the release of bound phenolic compounds and to a slight increase of TPC [44]. Another hypothesis deals with chemical changes in phytocompounds or conversion of glycosylated phenolics into their aglycones. As evidenced by results in Table 7, yeast fermentation allows a total phenols increase from $706 \mu \mathrm{g}_{\mathrm{GAE}} / \mathrm{g}_{\mathrm{dw}}$ in kneaded bread dough to $777 \mu \mathrm{g}_{\mathrm{GAE}} / \mathrm{g}_{\mathrm{dw}}$ in fermented one. Conversely, the change in antioxidant activity is not statistically relevant.

Table 7. Phenol content and antioxidant activity in nettle enriched bread production steps.

\begin{tabular}{ccc}
\hline Bread Sample & $\begin{array}{c}\text { TPC }^{\mathbf{1}} \\
\left(\boldsymbol{\mu g}_{\mathrm{GAE}} / \mathbf{g}_{\mathbf{d w}}\right)^{\mathbf{2}}\end{array}$ & $\begin{array}{c}\text { TEAC }^{\mathbf{1}} \\
\left(\mathbf{m g}_{\mathrm{TE}} / \mathbf{g}_{\mathbf{d w}}\right)^{\mathbf{3}}\end{array}$ \\
\hline Kneaded & $706 \pm 11$ & $0.80 \pm 0.07$ \\
Fermented & $777 \pm 15$ & $0.79 \pm 0.10$ \\
Pre-baked & $779 \pm 9$ & $0.72 \pm 0.06$ \\
Baked & $835 \pm 23$ & $1.16 \pm 0.10$ \\
\hline
\end{tabular}

TPC, total phenols content. TEAC, antioxidant activity. ${ }^{1}$ values are expressed as mean $\pm \mathrm{SD}, n=3 .{ }^{2} \mu \mathrm{g}$ of gallic acid equivalents (GAE) per $\mathrm{g}$ of dried weight $(\mathrm{dw}){ }^{3} \mathrm{mg}$ of trolox equivalents (TE) per $\mathrm{g}$ of dried weight (dw).

Additionally, there are numerous evidences in literature works about an increase in TPC value due to both baking process and the concurring Maillard reaction [43,45]. Indeed, our results (Table 7) show the increase of TPC from $777 \mu \mathrm{g}_{\mathrm{GAE}} / \mathrm{g}_{\mathrm{dw}}$ in fermented bread dough to $835 \mu \mathrm{g}_{\mathrm{GAE}} / \mathrm{g}_{\mathrm{dw}}$ in fully baked bread, and at the same time TEAC raises from $0.79 \mathrm{mg}_{\mathrm{TE}} / \mathrm{g}_{\mathrm{dw}}$ to $1.16 \mathrm{mg} \mathrm{TE}_{\mathrm{TE}} / \mathrm{g}_{\mathrm{dw}}$. Both TPC and TEAC do not significantly change between fermented dough and pre-baked stages. These findings can be manly due by the release of antioxidant compounds and the loss of water during cooking procedure: as a matter of fact the relative humidity dropped from $39.9 \%$ for kneaded bread to $28.5 \%$ for baked bread. For this reason TPC and TEAC quantities are calculated on the basis of dry weight and their final estimates undoubtedly confirm that phenolic content and antioxidant activity of white bread can be improved by both nettle enrichment and breadmaking process.

These results are preliminary but fundamental for a clearer understanding of the entire enrichment process and its future perspectives in functional food research. What we have found and discussed here will be applied in the following to deeply investigate the true effects of enriched foods on gastrointestinal system and human health. Staple enriched food as a delivery medium for micronutrients, dietary fibers and antioxidants represents one of the most effective ways of achieving healthier foodstuff and counteracting nutritional deficiencies in population groups (i.e., children, elders, people affected by gastrointestinal diseases).

\section{Conclusions}

In this study the comparison between white bread and nettle-enriched bread was carried out with a major focus on the chemical composition of both processed foods and with particular attention to those functional characteristics that improve the quality of nettle-enriched bread. It has been demonstrated that the addition of nettle can significantly increase the level of fibers, calcium and copper, and in a lesser way also the iron content. Nettle-enriched bread evidenced a total phenolic content higher than plain white bread and its exhibited antioxidant activity is superior in the same way than non-enriched bread. This went along with an increment in the concentration of lutein and $\beta$-carotene, two important carotenoids involved in free-radical scavenging activity. Changes in all these 
parameters were monitored during main breadmaking steps for large scale retail trade. The most interesting results were obtained for total phenols and antioxidant activity in enriched bread. In fact, values of TPC and TEAC increased from kneaded to fermented dough and then again moved up when fermented dough was baked.

Our findings confirm that the nettle leaves are a valuable ingredient for the development of enriched foods with improved nutritional and functional properties. This can be done on a large scale production such as breadmaking. Additionally, the enhanced antioxidant features of enriched bread might exert interesting nutritional benefits, such as protective effects with respect the mitochondrial gene expression in the presence of cereal mycotoxins. This represents a driver for future research in this field, as recently evidenced from the role of dietary carotenoids against aflatoxins and enniatins [46].

Author Contributions: Conceptualization, A.M. and N.M.; methodology, M.C., L.P. and A.C.; formal analysis, P.T. and C.S.; investigation, A.M. and N.M.; writing-original draft preparation, A.M.; writing-review and editing, N.M.; supervision, N.M.; funding acquisition, A.M. All authors have read and agreed to the published version of the manuscript.

Funding: This research was funded by the joint grant CCIAA-University of Ferrara (2016).

Institutional Review Board Statement: Not applicable.

Informed Consent Statement: Not applicable.

Data Availability Statement: Not applicable.

Acknowledgments: Authors thank Vassalli Bakering S.r.l. for provided samples and partnership.

Conflicts of Interest: The authors declare no conflict of interest.

\section{References}

1. Kelly, T.; Yang, W.; Chen, C.S.; Reynolds, K.; He, J. Global burden of obesity in 2005 and projections to 2030. Int. J. Obes. 2008, 32, 1431-1437. [CrossRef]

2. Popkin, B.M. Global nutrition dynamics: The world is shifting rapidly toward a diet linked with noncommunicable diseases. Am. J. Clin. Nutr. 2006, 84, 289-298. [CrossRef]

3. Ames, B.N.; Wakimoto, P. Are vitamin and mineral deficiencies a major cancer risk? Nat. Rev. Cancer 2002, 2, 694-704. [CrossRef]

4. Menrad, K. Market and marketing functional food in Europe. J. Food Eng. 2003, 56, 181-188. [CrossRef]

5. Szakály, Z.; Szente, V.; Kövér, G.; Polereczki, Z.; Szigeti, O. The influence of lifestyle on health behavior and preference for functional foods. Appetite 2012, 58, 406-413. [CrossRef] [PubMed]

6. Balestra, F.; Cocci, E.; Pinnavaia, G.G.; Romani, S. Evaluation of antioxidant, rheological and sensorial properties of wheat flour dough and bread containing ginger powder. LWT Food Sci. Technol. 2011, 44, 700-705. [CrossRef]

7. Crassina, K.; Sudha, M.L. Evaluation of rheological, bioactives and baking characteristics of mango ginger (Curcuma amada) enriched soup sticks. J. Food Sci. Technol. 2015, 52, 5922-5929. [CrossRef] [PubMed]

8. Kadam, S.U.; Prabhasankar, P. Marine foods as functional ingredients in bakery and pasta products. Food Res. Int. 2010, 43, 1975-1980. [CrossRef]

9. Colantuono, A.; Ferracane, R.; Vitaglione, P. Potential bioaccessibility and functionality of polyphenols and cynaropicrin from breads enriched with artichoke stem. Food Chem. 2018, 245, 838-844. [CrossRef]

10. Gawlik-Dziki, U.; Swieca, M.; Dziki, D.; Baraniak, B.; Tomiło, J.; Czyz, J. Quality and antioxidant properties of breads enriched with dry onion (Allium cepa L.) skin. Food Chem. 2013, 138, 1621-1628. [CrossRef]

11. Hu, G.; Huang, S.; Cao, S.; Maa, Z. Effect of enrichment with hemicellulose from rice bran on chemical and functional properties of bread. Food Chem. 2009, 115, 839-842. [CrossRef]

12. Gökmen, V.; Mogo Ataç, B.A.; Barone Lumaga, R.; Fogliano, V.; Kaplun, Z.; Shimoni, E. Development of functional bread containing nanoencapsulated omega-3 fatty acids. J. Food Eng. 2011, 105, 585-591. [CrossRef]

13. Guarrera, P.M.; Savo, V. Perceived health properties of wild and cultivated food plants in local and popular traditions of Italy: A review. J. Ethnopharmacol. 2013, 146, 659-680. [CrossRef]

14. Sansanelli, S.; Tassoni, A. Wild food plants traditionally consumed in the area of Bologna (Emilia Romagna region, Italy). J. Agric. Chem. 2014, 10, 1-11. [CrossRef]

15. Upton, R. (R.H. DAyu) Stinging nettles leaf (Urtica dioica L.): Extraordinary vegetable medicine. J. Herb. Med. 2013, 3, 9-38. [CrossRef]

16. Bonetti, G.; Tedeschi, P.; Meca, G.; Bertelli, D.; Manes, J.; Brandolini, V.; Maietti, A. In vitro bioaccessibility, transepithelial transport and antioxidant activity of Urtica dioica L. phenolic compounds in nettle based food products. Food Funct. 2016, 7, 4222-4230. [CrossRef] 
17. Marchetti, N.; Bonetti, G.; Brandolini, V.; Cavazzini, A.; Maietti, A.; Meca, G.; Mañes, J. Stinging nettle (Urtica dioica L.) as a functional food additive in egg pasta: Enrichment and bioaccessibility of Lutein and $\beta$-carotene. J. Funct. Foods 2018, 47, 547-553. [CrossRef]

18. AOAC. Official Methods of Analysis, 14th ed.; Association of Official Analytical Chemists: Washington, DC, USA, 1984.

19. ISO. Milk-Determination of Nitrogen Content; International Organization for Standardization: Geneva, Switzerland, 2004.

20. Prosky, L.; Asp, N.G.; Schweizer, T.F.; de Vries, J.W.; Furda, L. Determination of insoluble, soluble, and total dietary fibre in foods and food products. J. Assoc. Off. Anal. Chem. 1988, 71, 1017-1023. [PubMed]

21. Lee, S.C.; Prosky, L.; de Vries, J.W. Determination of total, soluble and insoluble fiber in foods-enzymatic-gravimetric method. J. Assoc. Off. Anal. Chem. 1992, 75, 395-416.

22. Ertl, K.; Goessler, W. Grains, whole flour, white flour, and some final goods: An elemental comparison. Eur. Food Res. Technol. 2018, 244, 2065-2075. [CrossRef]

23. Pérez-Jiménez, J.; Saura-Calixto, F. Literature data may underestimate the actual antioxidant capacity of cereals. J. Agric. Food Chem. 2005, 53, 5036-5040. [CrossRef]

24. Singleton, V.L.; Thofer, R.O.; Lamuela-Raventós, R.M. Analysis of total phenols and other oxidation substrates and antioxidants by means of folin-ciocalteu reagent. Method Enzymol. 1999, 299, 152-178.

25. Re, R.; Pellegrini, N.; Proteggente, A.; Pannala, A.; Yang, M.; Rice-Evans, C. Antioxidant activity applying an improved ABTS radical cation decolorization assay. Free Radic. Biol. Med. 1999, 26, 1231-1237. [CrossRef]

26. Panfili, G.; Fratianni, A.; Irano, M. Improved normal-phase high-performance liquid chromatography procedure for the determination of carotenoids in cereals. J. Agric. Food Chem. 2004, 52, 6373-6377. [CrossRef]

27. Bergantin, C.; Maietti, A.; Tedeschi, P.; Font, G.; Manyes, L.; Marchetti, N. HPLC-UV/Vis-APCI-MS/MS determination of major carotenoids and their bioaccessibility from "Delica" (Cucurbita maxima) and "Violina" (Cucurbita moschata) pumpkins as food traceability markers. Molecules 2018, 23, 2791. [CrossRef]

28. Adhikari, B.M.; Bajracharya, A.; Shrestha, A.K. Comparison of nutritional properties of Stinging nettle (Urtica dioica) flour with wheat and barley flours. Food Sci. Nutr. 2015, 4, 119-124. [CrossRef]

29. Tokalioglu, S. Determination of trace elements in commonly consumed medicinal herbs by ICP-MS and multivariate analysis Food Chem. 2012, 134, 2504-2508. [CrossRef]

30. Edwards, S.C.; Macleod, C.L.; Lester, J.N. The bioavailability of copper and mercury to the common nettle (Urtica dioica) and the earthworm eisenia fetida from contaminated dredge spoil. Water Air Soil Pollut. 1998, 102, 75-90. [CrossRef]

31. Joshi, B.C.; Mukhija, M.; Kalia, A.N. Pharmacognostical review of Urtica dioica L. Int. J. Green Pharm. 2014, 8, $201-209$.

32. Alemayehu, D.; Desse, G.; Abegaz, K.; Desalegn, B.B.; Getahun, D. Proximate, mineral composition and sensory acceptability of homemade noodles from Stinging Nettle (Urtica simensis) leaves and wheat flour blends. Int. J. Food Sci. Nutr. Eng. 2016, 6, 55-61.

33. Lombardi-Boccia, G.; Aguzzi, A.; Cappelloni, M.; Di Lullo, G.; Lucarini, M. Total-diet study: Dietary intakes of macro elements and trace elements in Italy. Br. J. Nutr. 2003, 90, 1117-1121. [CrossRef]

34. Wapnir, R.A. Copper absorption and bioavailability. Am. J. Clin. Nutr. 1998, 67, 1054S-1060S. [CrossRef]

35. Zimmermann, M.B.; Hurrell, R.F. Nutritional iron deficiency. Lancet 2007, 370, 511-520. [CrossRef]

36. Okarter, N.; Liu, C.S.; Sorrells, M.E.; Liu, R.H. Phytochemical content and antioxidant activity of six diverse varieties of whole wheat. Food Chem. 2010, 119, 249-257. [CrossRef]

37. Laddomada, B.; Caretto, S.; Mita, G. Wheat bran phenolic acids: Bioavailability and stability in whole wheat-based foods. Molecules 2015, 20, 15666-15685. [CrossRef]

38. Vogrincic, M.; Timoracka, M.; Melichacova, S.; Vollmannova, A.; Kreft, I. Degradation of rutin and polyphenols during the preparation of tartary buckwheat bread. J. Agric. Food Chem. 2010, 58, 4883-4887. [CrossRef]

39. Das, L.; Raychaudhuri, U.; Chakraborty, R. Supplementation of common white bread by coriander leaf powder. Food Sci. Biotechnol. 2012, 21, 425-433. [CrossRef]

40. Glei, M.; Kirmse, A.; Habermann, N.; Persin, C.; Pool-Zobel, B.L. Bread enriched with green coffee extract has chemoprotective and antigenotoxic activities in human cells. Nutr. Cancer 2006, 56, 182-192. [CrossRef]

41. Leenhardt, F.; Lyan, B.; Rock, E.; Boussard, A.; Potus, J.; Chanliaud, E.; Remesy, C. Wheat lipoxygenase activity induces greater loss of carotenoids than vitamin E during breadmaking. J. Agric. Food Chem. 2006, 54, 1710-1715. [CrossRef]

42. Hidalgo, A.; Brandolini, A.; Pompei, C. Carotenoids evolution during pasta, bread and water biscuit preparation from wheat flours. Food Chem. 2010, 121, 746-751. [CrossRef]

43. Dziki, D.; Rozylo, R.; Gawlik-Dzikic, U.; Swieca, M. Current trends in the enhancement of antioxidant activity of wheat bread by the addition of plant materials rich in phenolic compounds. Trends Food Sci. Tech. 2014, 40, 48-61. [CrossRef]

44. Adebo, O.A.; Medina-Meza, I.G. Impact of fermentation on the phenolic compounds and antioxidant activity of whole cereal grains: A mini review. Molecules 2020, 25, 927. [CrossRef]

45. Gelinas, P.; McKinnon, C.M. Effect of wheat variety, farming site, and bread-baking on total phenolics. Int. J. Food Sci. Technol. 2006, 41, 329-332. [CrossRef]

46. Alonso-Garrido, M.; Tedeschi, P.; Maietti, A.; Font, G.; Marchetti, N.; Manyes, L. Mitochondrial transcriptional study of the effect of aflatoxins, enniatins and carotenoids in vitro in a blood brain barrier model. Food Chem. Toxicol. 2020, 137, 111077. [CrossRef] 